\title{
Mechanical Characteristics of Joints Between Glass Fiber Reinforced Composite Tubes and Steel Cylinder Obtained by Different Fastening Elements
}

\author{
Jovan Radulović ${ }^{1)}$ \\ Slobodan Čitaković ${ }^{1)}$
}

\begin{abstract}
In this paper, investigation of tensile testing for-specific assemblies of two elements, jointed by mechanical fasteners, are presented. One element is a specific small diameter tube. This element is produced by filament winding technology using glass fiber impregnated with polyester resin. Another element is cylindrical steel part, obtained by standard technology. Basic data about composite materials and mechanical fastening are presented. Pins and rings were used as mechanical fasteners. Data of tubes preparation and assembling glass fiber/polyester resin tubes and cylinder with pins and rings are presented. The assemblies specific composite material parts/metallic parts jointed by fasteners were exposed to the action of axial tensile stress. A tensile breaking force of the assemblies was determined and the influence of pins number to tensile breaking force was presented. A failure mechanism of specific composite tubes fastened with pins and rings is described
\end{abstract}

Key words: polymeric materials, composite materials, glass fibre, filament winding, tube, steel, ring, mechanical joining, mechanical characteristics, tensile strength.

\section{Introduction}

$\mathrm{M}$ ATERIALS are the basic elements of all natural and man-made structures. Technological progress is associated with continuous improvement of existing material properties, as well as with expansion of structural material classes and types. Usually, new materials emerge due to the need to improve structural efficiency and performance. In addition, as a rule, new materials themselves in turn provide new opportunities to develop updated structures and technology, which then challenge materials science with new problems and tasks. One of the best manifestitations of this interrelated process in the development of materials, structures, and technology is associated with the composite materials and structural elements[1]. Until early 1990s, the use of fiberreinforced polymer composites was almost limited to only aerospace and military applications. By the mid-1990s, civil engineers started to realize the advantages of such materials and to use them. The introduction of composite materials in the automotive industry, places new demands on the materials and manufacturing processes in terms of cost, cycle time and automation. Manufacture and assembly of composite structures require knowledge of reliable joining techniques.

High performance composite materials are nowadays widely employed in many advanced engineering fields due to the overall set of characteristics. Primarily mechanical properties of these materials make them attractive for structural applications where high strength-to-weight and stiffness'-to-weight ratios are required. High-performance composites satisfy the requirements for high specific strength and specific stiffness, low coefficient of thermal expansion, good fatigue resistance, high damping properties, dimensional stability during the operational lifetime and, also, offer the minimum weight material solution for these structures. The joint of structural elements, made of fiber reinforced polymer materials or other materials, requires connections, which are therefore integral parts of a structure and can be classified as:

- Primary structural connections, whose integrity is crucial to the function and safety of a structure. They are designed to provide a major strength and stiffness to the structural joint for the life of the structure,

- Secondary structural connections, which provide some strength and stiffness to the joint, but their failure would not cause damage beyond the structural elements they join. An example is the field connection of two modular units and

- Non-structural connections, e.g., joints of decorative panels [2].

\section{Composite materials}

The term composite originally arose in engineering when two or more materials were combined in order to rectify shortcomings of particularly useful components [3]. By recently introduced definition, composite material is a system composed of two or more physically discinct phase whose combination produces aggregate properties that are different from those of its constituents [4]. The term phase indicates homogeneous material, such is metal or ceramic, in which all of the grain have the same crystal structure, or a polymer with no fillers. In the simplest case, composite materials consist of two phases: a primary phase and a secondary phase. The primary phase forms the matrix within which the secondary phase is embedded. The primary phase is called impregnating agent, and the secondary phase is called reinforcing agent, because it usually serves to strenghten the composite. The phases are generally insoluble in each other, but strong adhesion must exsist at their interfaces. The matrix phase can be any of three basic material types (polymer, metal and ceramics) and the secondary phase may be, also, any of the three mentioned materials or elements (carbon, boron) [4]. One of the composite materials production technology

\footnotetext{
1) Military Technical Institute (VTI), Ratka Resanovića 1, 11132 Belgrade, SERBIA

Correspondence to: Jovan Radulović; e-mail: jovan.r.radulovic@gmail.com
} 
increasingly used is the filament winding technology. Filament wound polymeric composites consist of a reinforcing agent and an impregnating agent. Reinforcing agents can be polymer-based (carbon fibres, graphite fibres, aromatic polyamide fibres (aramide), novoloid fibres, etc) and nonpolymeric (glass fibres) ones. Impregnating agents are mostly polymeric (polyester resins, epoxy resins, phenolic resins and other thermoreactive resins). Glass fibers are available in many forms for producing different commercial and industrial products. Materials in form of fibres are often vastly stronger than the same material in bulk form. Glass fibres, for example, may have tensile strength from 4,8 $\mathrm{MPa}$ (commercial fibres) to $7 \mathrm{MPa}$ (laboratory samples) whereas massive plate glass breaks of stresses about $7 \mathrm{kPa}$ (1000 times lower). There are many glass fiber types: A- glass (alkaline), C-glass (chemical), D-glass (dielectric), E-glass (electricalnonalkaline), E-CR-glass (corrosion resistant), R- and S-glass (higher tensile strength), M-glass (high modulus), Advantexglass (ecological, high quality), Zen Tron-glass (higher impact resistance), etc... For reinforcement of polymer materials, glass fibers are used in continuous and discontinuous forms [5]. For filament winding technology glass fibers are used in continuous form, i.e. in roving form (roving is a bundle of nontwisted fibres, theoretically of endless length) [6]. Glass fibres are mostly used (over $90 \%$ of all reinforcements) with thermorective and thermoplastic matrixes for increased strength, dimensional stability, corrosion resistance, thermal stability, dielectrical propreties and so on [5]. It is considered that there are more than 5.000 of composite polymeric materials. The global tonnage of composite materials was about 10 million tones in 2015 [7,8]. The filament winding technology, in brief, consists of winding fiber reinforcing agents previously impregnated by a resin impregnating system on the mandrel, curing wound structure and removing the cured product from the tool [3]. Based on theoretical considerations and practical experience on the investigation and development of polymeric composite filament-wound materials, it is known that the characteristics of the mentioned materials depend on the reinforcing agent and the impregnating agent as well as on the technological parameters of the production process [6]. Filament-wound composite materials have the unique set of specific characteristics. Considering extreme versatility of the used materials and technological parameters (especially winding angle, number and sequence of wound layers), almost every filament-wound product has unique properties, especially those built in complex assemblies [9].

\section{Mechanical fastening of joint elements}

For a high volume production of joints, mostly mechanical fasteners, adhesive bond, molded-in inserts and electromagnetic and induction heating of adhesives are used.

For a production of fewer number of joints, i.e. for low volume production of assembly mechanical fastening and adhesive bonding are used.

As it can be seen, mechanical fastening is ajoining technique widely used for a high volume production and for a low volume production of an assembly [10].

In the simplest manner the mechanical fastener is a device that joints materials.

Fiber reinforced materials, particularly continuous fiber reinforced polymeric materials, become more widely used. An important requirement for their full exploitation is development of general joint considerations and suitable attachments method $[11,12]$.
It is considered that joining is a procedure in which a polymeric part is bonded to another part that is composed of the same or different polymeric material, as well as other material (such as metal). This procedure is necessary when (1) the finished assembly is too complex or large to fabricate in one piece, (2) disassembly and reassembly is necessary, for cost reduction or (3) when different materials must be used within the finished assembly [13].

As with metals, demountable joints are needed in FRP structures where there is a call for inspection and servicing, modification, repair or replacement or damaged or worn components or in situation where adhesive bonding is uneconomic or impractical.

With the increasing interest in the use of mechanical fasteners for joining fiber reinforced polymeric (FRP) components, a variety of fastening techniques that are used for metals have been successfully applied to many forms of FRP parts. In lightly loaded connections a self-tapping screws are mounted, while for quality engineering heavily loaded strucrures, bolts or pins are used [12].

There are similarities and differences in behaviour of failured joints consisting of two metallic elements and joints in which one or both components made of fiber reinforced polymeric composite materials are present. At metallic structures, a tension, shear and so called bearing failure modes can be seen. Due to the complex failure mechanism of fiber reinforced polymeric composite materials, two addittional failure modes are possible, namely cleavage and pullout.

Mechanically fastened joints are exposed to different kind of external forces. In practice, external force can cause no catastrophic and catastrophic failure mode of mechanically fastened joint [13].

No catastrophic failure mode of mechanically fastened joint is so called bearing failure mode, presented in Fig.1.

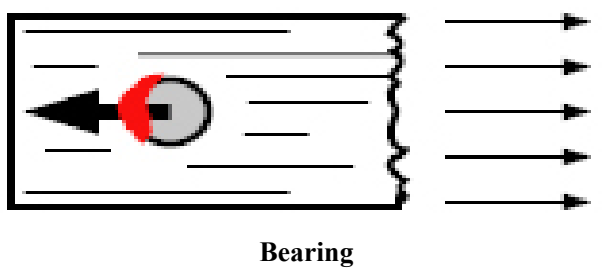

Figure 1. The bearing failure mode

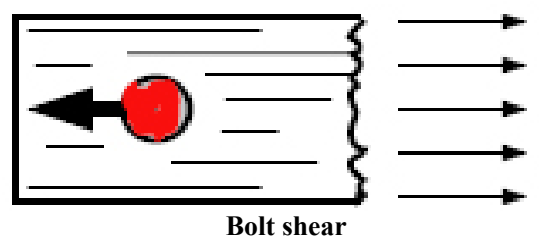

Figure 2. The bolt shear failure mode

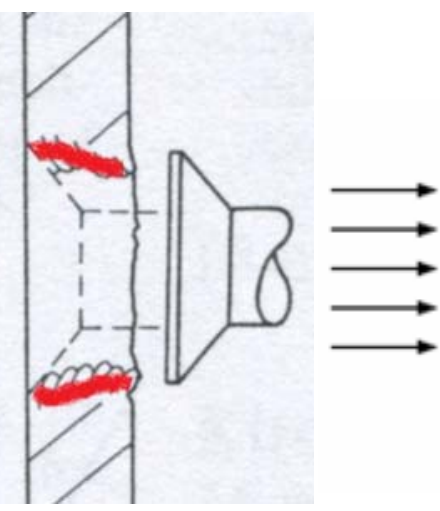

Figure 3. The pullout failure mode 
Catastrophic failure mode of mechanically fastened joint can be associated with the fastener (so called bolt shear, presented in Fig.2 and pullout, presented in Fig.3) and composite material.

Catastrophic failure mode of mechanically fastened joint associated with the composite material can be tension, shearout and cleavage, presented in Figures 4-6, respectively.

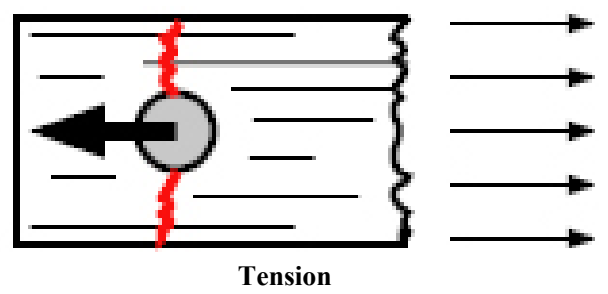

Figure 4. The tension failure mode

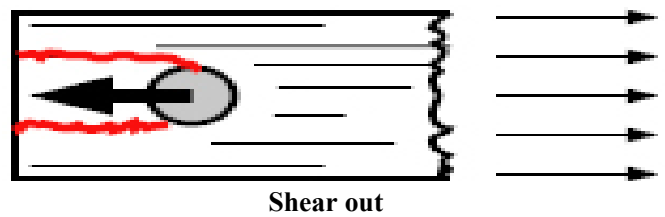

Figure 5. Shear-out failure mode

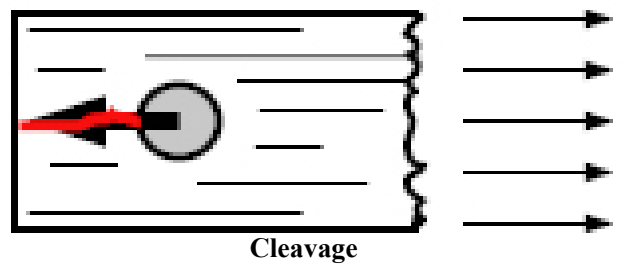

Figure 6. The cleavage failure mode

In this paper, investigation results of tensile testing of joint between specific polymeric composite element and metallic element, realized by pins and ring, are presented. Specific polymeric composite element is a tube, produced by filament winding technology of glass fiber impregnated by polyester resins. The metallic element is a steel cylinder, produced by standard machining. Data of tubes samples production, assembling composite tubes and cylinder with pins, tensile breaking force of mentioned assemblies and modes of tubes failure are presented. This paper, also, contains data of joining polyester resin/glass fiber tubes with the cylinder using rings, tensile breaking force of these assemblies and modes of tubes failure.

Xiao and Ishikawa studied the strength and failure in mechanically fastened pressed graphite/polyimide composite and graphite/epoxy composite. The observations indicate that the bearing failure can be outlined as a process of compressive damage accumulation, and can be divided into the following four stages: damage onset; damage growth; local fracture; structural fracture [14].

Camanho and Lambert predicted the onset of a damage, final failure and failure mode of mechanically fastened joints in composite laminates with experimental data obtained in pin- and bolt-loaded joints. The results indicate that the methodology proposed can accurately and effectively predict the ultimate failure loads as well as failure modes in composite bolted joints [15].

Esendemir and Ondurucu compared the bearing strength of bolted joint of glass/epoxy composite with different clearances and tested the joint under two different boltbearing conditions. It is observed that this parameter has important influence on the failure load of mechanically fastened joints [16].
Toppul et.al. investigated the mechanics of mehanically fastened joints in polymer-matrix structures. They presented relevant mechanical test methods and standards, mechanic aspects of design, including joint design methodologies, considerations of the influence of geometric effects, failure modes such as bearing failure, failure prediction for both statically and dynamically loaded joints, time-dependent joint preload relaxation, the effects of temperature and moisture on joint strength and failure, and non-destructive evaluation techniques for monitoring the joints [17].

\section{Experimental part}

\section{The preparation of tube samples}

Tubes, used in the experiments, were prepared by filament winding of an E glass roving R 2117 trade mark (made by glass fibre manufacturer "ETEX", Baljevac/Ibar) impregnated by impregnating polyester resin system DUGAPOL H 230 trade mark (made by polyester resin manufacturer "DUGA", Belgrade) with addittion of inhibitor trade mark TBC (produced by chemical producer AKZO, Holland).

The tubes were wound on a cylindrical mandrel using the PLASTEX type PLA 500 machine (made by machine manufacturer PLASTEX-MANUHRINE, France).

Winding structure denotes winding angle, number and sequence of layers. Winding angle is an angle which reinforcing agent (fiber) forms regarding longitudinal axe of product.

By machining process, tube samples $250 \mathrm{~mm}$ long were cut from the cured tubes.

Fastening elements, used for these experiments, are pins with cylindrical head (for the purpose of this paper abbreviated: pins and rings.

\section{The preparation of tube samples intended for joints fastened with pins}

Using glass fibre/polyester resin tube samples, the appropriate $5 \mathrm{~mm}$ diameter holes, whose center is $25 \mathrm{~mm}$ from the ends of the tube samples $250 \mathrm{~mm}$ long, were produced.

Joint tube sample-pin-cylinder is realised in a way that pin is passing through the hole of a tube sample and entering cylinder, as presented in Fig.7.

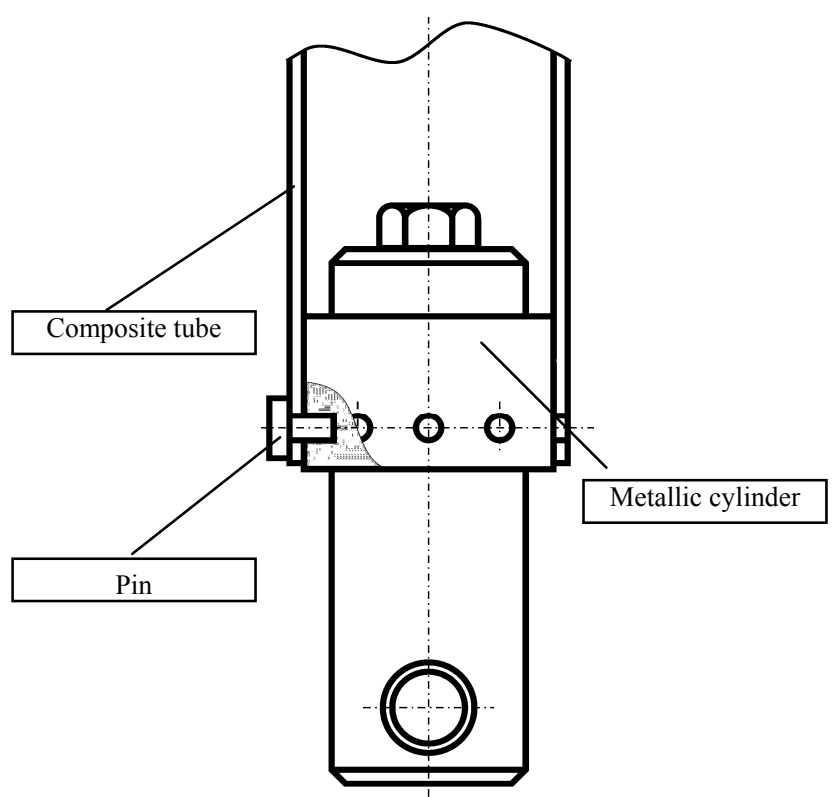

Figure 7. Sketch of a tube sample-pin-cylinder joint 
Pins are presented in Fig.8.

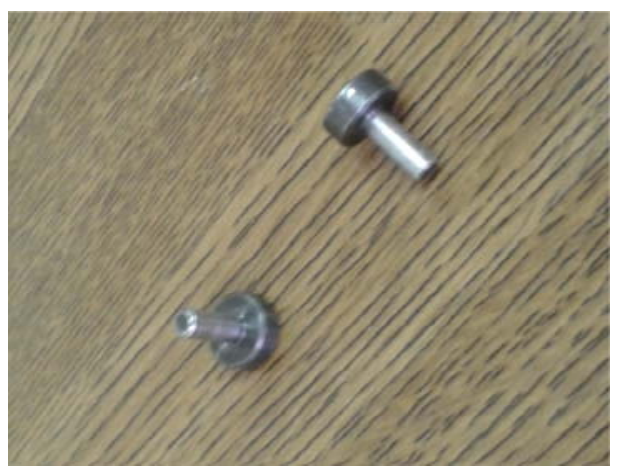

Figure 8. Pins

The specimen marks, the winding structure (from the inside toward the outside), hole number, internal diameter, external diameter and wall thickness of tube samples are presented in Table 1.

Table 1. Specimen marks, the winding structure, hole number internal diameter, external diameter and wall thickness of tube samples

\begin{tabular}{|c|c|c|c|c|c|}
\hline $\begin{array}{l}\text { Specimen } \\
\text { marks }\end{array}$ & $\begin{array}{l}\text { Winding } \\
\text { structure }\end{array}$ & $\begin{array}{c}\text { Hole } \\
\text { number }\end{array}$ & $\begin{array}{c}\text { Internal di- } \\
\text { ameter } \\
(\mathrm{mm})\end{array}$ & $\begin{array}{l}\text { External di- } \\
\text { ameter } \\
(\mathrm{mm})\end{array}$ & $\begin{array}{c}\text { Wall thick- } \\
\text { ness } \\
(\mathrm{mm})\end{array}$ \\
\hline $4 \mathrm{P}$ & \multirow{4}{*}{$\begin{array}{l}1 \times 90^{\circ} \\
2 \times 61^{\circ} \\
1 \times 90^{\circ}\end{array}$} & 4 & 64,20 & 67,60 & 1,70 \\
\hline $6 \mathrm{P}$ & & 6 & 64,20 & 67,60 & 1,70 \\
\hline $8 \mathrm{P}$ & & 8 & 64,20 & 67,60 & 1,70 \\
\hline $12 \mathrm{P}$ & & 12 & 64,20 & 67,60 & 1,70 \\
\hline
\end{tabular}

For the purpose of this paper, next abbreviations will be used:

- "Specimen 4P" is a joint consisting of the tube with four holes fastened with metallic cylinder by $\mathbf{4}$ pins,

- "Specimen 6P" is a joint consisting of the tube with six holes fastened with metallic cylinder by 6 pins,

- "Specimen 8P" is a joint consisting of the tube with eight holes fastened with metallic cylinder by 8 pins,

- "Specimen 12P" is a joint consisting of the tube with twelve holes fastened with metallic cylinder by 12 pins.

The preparation of tube samples intended for joints fastened with rings

For the production of the tube samples intended for joints fastened with rings, a glass fiber/polyester resin cured tubes were used.

The winding structure (from inside toward the outside), internal diameter, external diameter and wall thickness of tube samples intended for joints fastened with ring are presented in Table 2.

Table 2. The winding structure, internal diameter, external diameter and wall thickness of tube samples intended for joints fastened with rings

\begin{tabular}{||c|c|c|c||}
\hline $\begin{array}{c}\text { Winding } \\
\text { structure }\end{array}$ & $\begin{array}{c}\text { Internal diameter } \\
(\mathrm{mm})\end{array}$ & $\begin{array}{c}\text { External diameter } \\
(\mathrm{mm})\end{array}$ & $\begin{array}{c}\text { Wall thickness } \\
(\mathrm{mm})\end{array}$ \\
\hline \hline $2 \times 90^{\circ}$ & & & \\
$4 \times 61^{\circ}$ & 64,20 & 71,00 & 3,40 \\
$2 \times 90^{\circ}$ & & & \\
\hline
\end{tabular}

On the internal surface of the tube samples $250 \mathrm{~mm}$ length, a groove depth $1,5 \mathrm{~mm}$ and $3,5 \mathrm{~mm}$ width is produced, at the distance of $25 \mathrm{~mm}$ from the end of a mentioned samples. One groove is produced at one end of tube sample, and another groove with same dimensions at the opposite end of the same tube sample.

During the production of a groove, both internal layers under the winding angle $90^{\circ}$ and one layer under the winding angle $61^{\circ}$ are completely removed and the second layer under the winding angle $61^{\circ}$ is almost completely removed. Practically, a half of the tube wall thickness is removed. By this manner, grooves on the internal surface of a tube sample are produced. Grooves of the same dimensions are produced on the outer surface of a metallic cylinder.

At one end of assembly, one ring is placed partially in groove on the internal surface of the tube sample and partially in groove on the outer surface of a metallic cylinder. Another ring is placed in the mentioned grooves on the opposite side of the assembly. Sketch of the tube sample-ring-cylinder joint is presented in Fig.9.

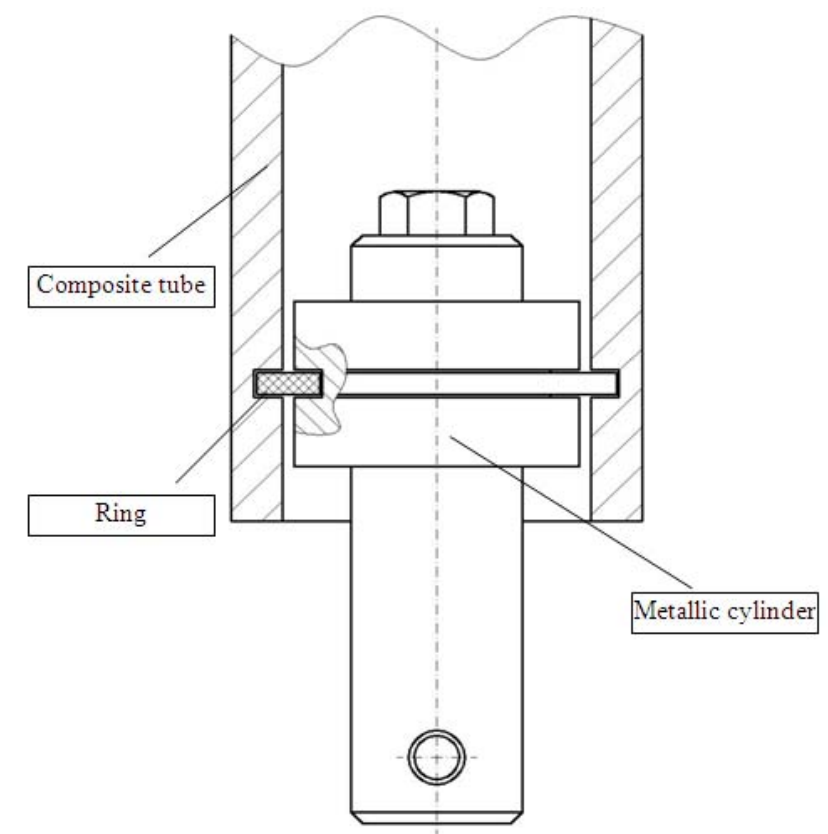

Figure 9. Sketch of the tube sample-ring-cylinder joint

Metallic, ring 3,15 mm wide and 3,15 mm thick (presented in Fig.10), is placed on the internal tube groove and on the external cylinder groove at girth $210 \mathrm{~mm}$ long.

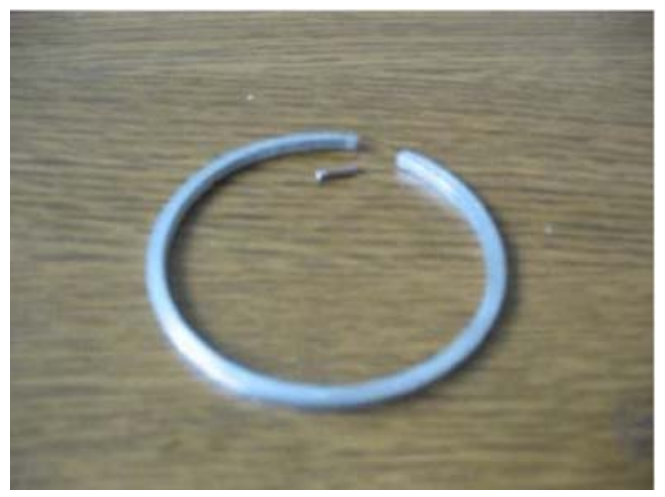

Figure 10. Metallic ring

Joint tube sample-ring-cylinder, produced in described manner, is exposed to the action of tensile stress.

\section{Results and discussion}

\section{Analysis of joints fastened with pins}

Joint, consisting of glass fiber/polyester resin composite tube with holes fastened with metallic cylinder by pins, was exposed to the action of tensile stress in axial direction. Testing was ended when the failure of the tube sample happened. 
Specimen marks, hole number, single values $\left(x_{i}\right)$ and arithmetic mean values and standard deviations $(\bar{x} \pm \delta)$ of the obtained tensile breaking force, are presented in Table 3 .

Table 3: Specimen marks, hole number, single values, arithmetic mean values and standard deviations of tensile breaking force of glass fiber/polyester resin tubes-ring-cylinder joint

\begin{tabular}{|c|c|c|c|c|c||}
\hline \multirow{2}{*}{$\begin{array}{c}\text { Specimen } \\
\text { mark }\end{array}$} & \multirow{2}{*}{$\begin{array}{c}\text { Hole } \\
\text { number }\end{array}$} & \multicolumn{4}{|c|}{ Tensile breaking force $(\mathrm{kN})$} \\
\cline { 3 - 6 } & & \multicolumn{3}{|c|}{ Single values $\left(x_{i}\right)$} & $\begin{array}{c}\text { Arithmetic mean values } \\
\text { and standard deviation } \\
(\bar{x} \pm \delta)\end{array}$ \\
\hline \hline 4P & 4 & 8,75 & 9,45 & 8,95 & $9,03 \pm 0,33$ \\
\hline $6 \mathrm{P}$ & 6 & 15,05 & 14,00 & 14,10 & $14,38 \pm 0,58$ \\
\hline $8 \mathrm{P}$ & 8 & 18,50 & 19,15 & 18,30 & $18,65 \pm 0,44$ \\
\hline $12 \mathrm{P}$ & 12 & 27,20 & 25,60 & 26,00 & $26,27 \pm 0,83$ \\
\hline
\end{tabular}

Specimen 4P, specimen 6P, specimen $8 \mathrm{P}$ and specimen $12 \mathrm{P}$, after the investigation of tensile breaking force, are presented in Figures 11-14, respectively.

As it can be seen in Fig.11, after an action of the axial tensile force, a failure of the tube with four holes, only happened in axial direction and no damage between pins at specimen $4 \mathrm{P}$ is observed.

Somewhat different situation can be seen in Fig.12. After the completed action of tensile force in axial direction, a damage of the tube with six holes in axial direction and in radial direction is observed. Damage of specimen 6P in radial direction between six pins is small but it exists.

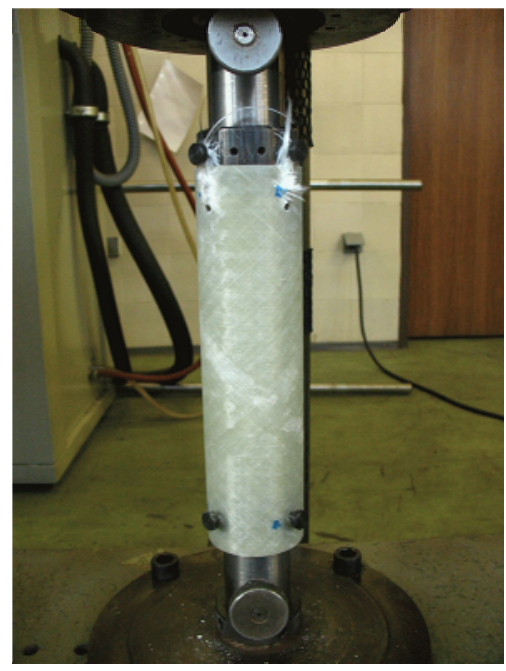

Figure 11. The specimen $4 \mathrm{P}$ after testing

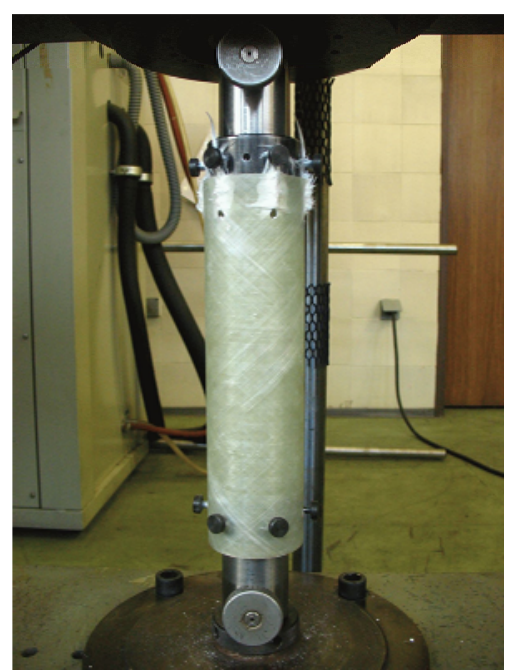

Figure 12. The specimen $6 \mathrm{P}$ after testing

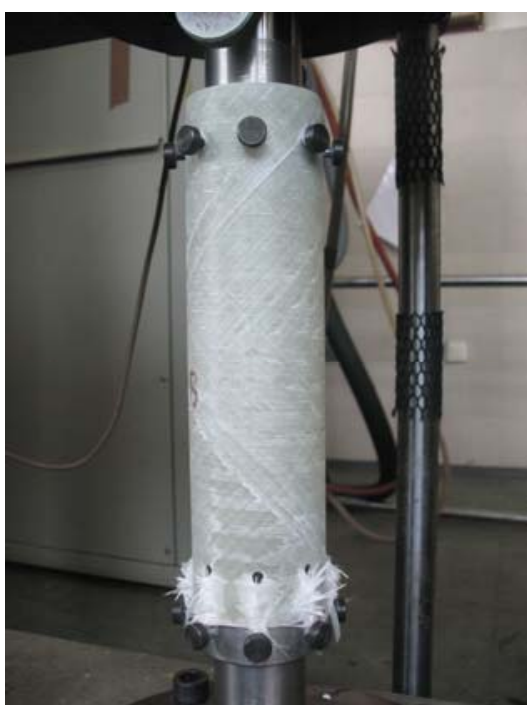

Figure 13. The specimen $8 \mathrm{P}$ after testing

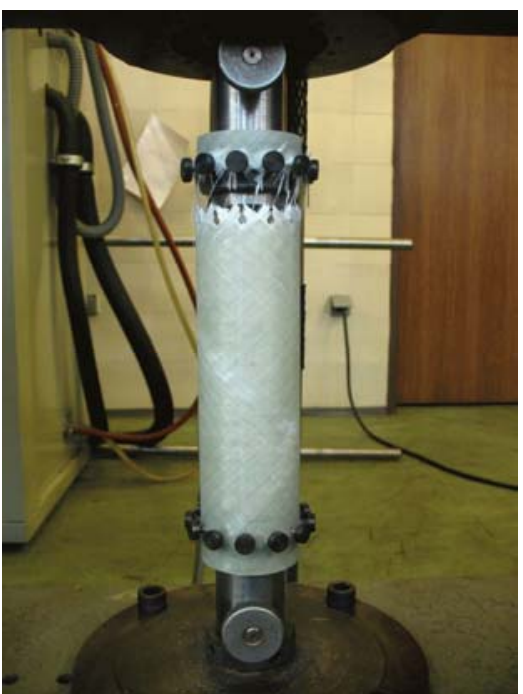

Figure 14. The specimen $12 \mathrm{P}$ after testing

The failure of specimen $8 \mathrm{P}$ is similar to the failure of specimen $6 \mathrm{P}$, because damages in axial and in radial directions are observed. As it can be seen in Fig.13, a damage between pins of specimen $8 \mathrm{P}$ with eight holes, i.e. damage in radial direction, is higher than at specimen $6 \mathrm{P}$.

In Fig. 14 a completely different fact is presented. After an action of tensile force only in axial direction at specimen $12 \mathrm{P}$ with twelve holes, the damage between pins causes catastrophic failure of the tube. Specimen $12 \mathrm{P}$ is catastrophically damaged at the positions between pins and part of the tube above pins, i.e. ring is separated from the remaining part of the tube.

Data presented in Table 3 pointed out that the specimen 4P, i.e. joint consisting of the tube with four holes fastened with a metallic part by 4 pins has the lowest tensile breaking force $(9,03 \pm 0,33 \mathrm{kN})$.

Tensile breaking force of the specimen 6P, i.e. joint consisting of the tube with six holes fastened with a metallic part by 6 pins is $(14,38 \pm 0,58) \mathrm{kN}$.

Arithmetic mean values and standard deviations of tensile breaking force of the specimen $8 \mathrm{P}$, i.e. joint consisting of the tube with eight holes fastened with a metallic part by 8 pins is $(18,65 \pm 0,44) \mathrm{kN}$

Specimen 12P, i.e. joint consisting of the tube with twelve holes fastened with a metallic part by 12 pins has the highest tensile breaking force $(26,27 \pm 0,83 \mathrm{kN})$. 


\section{Analysis of joints fastened with rings}

Joint, consisting of the composite tube with a groove on the internal surface and metallic cylinder with a groove on the external surface, fastened by rings, was exposed to the action of tensile stress in axial direction. Testing was ended when the failure of the tube sample happened.

Tube sample mark, single values $\left(x_{i}\right)$ and arithmetic mean value and standard devaitions $(\bar{x} \pm \delta)$ of investigation of tensile breaking force of polyester resin/glass fiber tube-ringcylinder joint, are presented in Table 4.

Table 4: Tube sample mark, single values $\left(x_{i}\right)$ and arithmetic mean value and standard devaitions $(\bar{x} \pm \delta)$ of tensile breaking force of polyester resin/glass fiber-ring-cylinder joint

\begin{tabular}{|c|c|c||}
\hline \multirow{2}{*}{$\begin{array}{c}\text { Tube sample } \\
\text { mark }\end{array}$} & $\begin{array}{c}|c| \\
\text { Single values } \\
\left(x_{i}\right)\end{array}$ & $\begin{array}{c}\text { Trithmetic mean value and standard de- } \\
\text { vaitions }(\bar{x} \pm \delta)\end{array}$ \\
\hline \hline P1 & 38,45 & \multirow{2}{*}{$41,3 \pm 3,9$} \\
\hline P2 & 45,73 & \\
\hline P3 & 39,75 & \\
\hline
\end{tabular}

An assembly polyester resin/glass fiber tube samplemetallic ring-metallic cylinder before and after testing is presented in Figures 15 and 16, respectively.

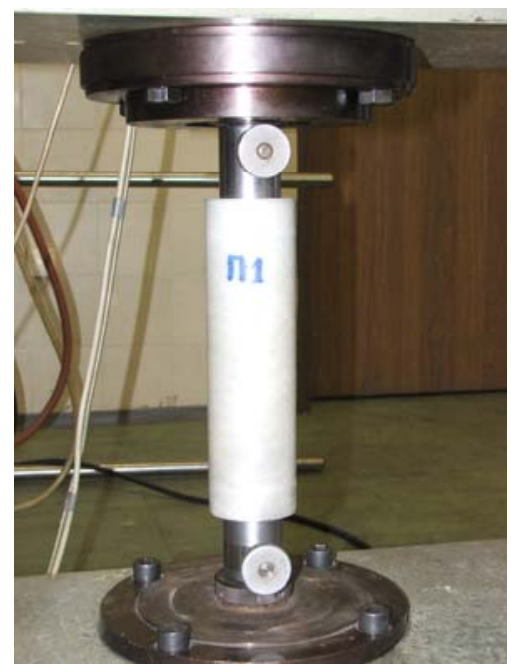

Figure 15. An assembly polyester resin/glass fiber tube-ring-cylinder before testing

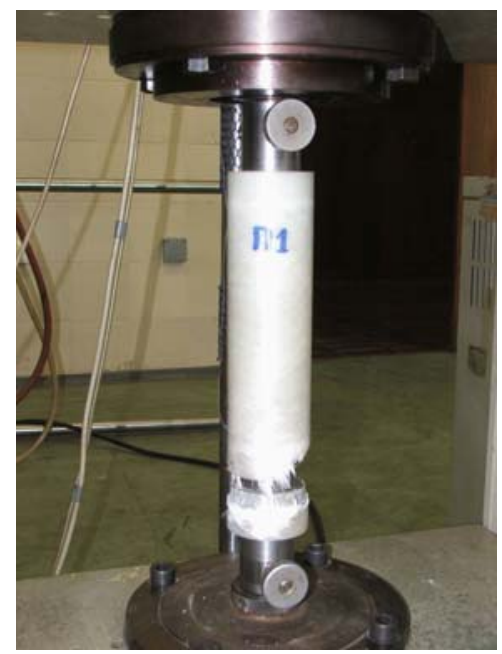

Figure 16. An assembly polyester resin/glass fiber tube ring-cylinder after testing

During the axial testing of the mentioned joints, a moving of metallic rings in a direction of the applied stress was observed.
This movement of metallic ring caused that kind of the tube sample damage so the complete separation of the ring tube part from the remaining tube part was observed. It was clearly visible that the tube sample was cut along a remaining wall thickness at the tube groove. Separtion of the ring tube part from the remaining tube part happened just at the place where the groove on the internal surface of the tube sample was produced. It is obvious that a failure of the tube sample in radial direction took place.

Based on the analysis of the presented data, it can be seen that tensile breaking force in axial direction of a joint filamentwound tube sample with polyester resin-ringscylinder is $(41,3 \pm 3,9) \mathrm{kN}$. During this testing a tube failure took place, which caused a breakage across the wall of the tube sample at the place where a groove is. Owing to this fact, the separation of one part of the tube from the remaining part of the tube happened, i.e. a failure in radial direction occured.

\section{Conclusions}

Based on the presented data, it can be concluded:

1. Tensile breaking forces of joint filament-wound glass fiber/polyester resin tubes-metallic cylinder, fastened by different number of pins, are investigated.

2. Number of pins has positive influence at tensile breaking forces of a specific polymeric composite part/metallic steel part assembly, fastened by mentioned joining element. The assembly with four pins has the lowest tensile breaking force $(9,03 \pm 0,33) \mathrm{kN}$ and the assembly with twelve pins has the highest tensile breaking force $(26,27 \pm 0,83) \mathrm{kN}$.

3. Pure cleavage failure mode was observed after testing the assembly consisting of the composite tube with four holes fastened with a machined steel part by 4 pins.

4. The assembly consisting of the composite tube with six holes fastened with a machined steel parts by 6 pins, showed mixed cleavage-tension failure mode.

5. Mixed tension-cleavage failure mode was observed after testing the assembly consisting of the tube with eight holes fastened with a machined steel part by 8 pins.

6. Pure tension failure mode was observed after testing the assembly consisting of the tube with twelve holes fastened with a machined steel part by 12 pins.

7. Determination of tensile breaking force of joint between filamentwound glass fiber/polyester resin tubes and metallic cylinder, fastened by rings, is done.

8. A radial failure of tube, at the location where groove was produced, was observed, after an action of axial tensile force at joint filamentwound glass fiber/polyester resin tubes-rings-metallic cylinder. A part of the tube, in a ring form, is separated from the remaining part of the tube.

9. Arithmetic mean value of tensile breaking force, which causes failure of filamentwound polyester resin/glass fiber tube fastened by rings with a metallic cylinder, is $(41,3 \pm$ $3,9) \mathrm{kN}$.

10. Making an analogy with failure modes of assemblies fastened with pins, one can say that this is the tension failure mode.

\section{Literature}

[1] VASILIEV,V.V., MOROZOV,E.V.: Advanced Mechanics of Composite Materials and Structural Elements, third edition, Elsevier Ltd., 2013, New York.

[2] DUTHINH,D.: Connections of Fiber-Reinforced Polymer (FRP) Structural Members: A Review of the State of Art, 2000, National Institute of Standards and Technology, Gaithersburg, USA. 
[3] RADULOVIĆ,J.: Filament Wound Composite Plastic Tubes: Relationship Between Winding Structures and their Hydraulic and Mechanical Properties, Scientific Technical Review, ISSN 1820-0206, 2011,Vol.61, No.3-4, pp.73-77.

[4] GROOVER,M.P.: Fundamentals of Modern Manufacturing, Materials, Processes and Systems, John Wiley and Sons Inc., Hoboken, 2010, ISBN 978-0470-467008.

[5] ROSATO,D.V., ROSATO,D.V.: Reinforced Plastics Handbook, 3rd ed., Elsevier Advanced Technology Ltd., Oxford, 2004, ISBN 18561 74506.

[6] RADUlOVIĆ,J.: Characterization Of Filamentwound Polymeric Composite Materials, Scientific Technical Review, ISSN 1820-0206, 2008, Vol.LVIII, No.1, pp.66-75.

[7] ASHBY,F.M.: Materials Selection in Mechanical Design, ButterworthHeinemann, Oxford, 1999

[8] GAY,D.: Composite Materials, Design and Applications, 3rd Ed.CRC Press, Taylor\&Francis Group, Boca Raton, 2015, ISBN 978-1-46658487-7

[9] RADULOVIĆ,J.: Influence of Internal Cyclic Pressure on Filamentwound Composite Tube Quality, Scientific Tehnical Review, ISSN 1820-0206, 2010, Vol.LX, No.1, pp.54-60.

[10] RADULOVIĆ,J.: Investigation Of External High And Moderate Water Pressure Influence On Sealed Thermoplastics Parts Assemblies Properties, Scientific Technical Review, ISSN 1820-0206, 2015, Vol.65, No.1, pp.15-22.
[11] ROSATO,D.V., ROSATO,M.G., ROSATO,D.V.: Concise Encyclopedia of Plastics, Kluwer Academic Publishers, Norwell, 2000, ISBN 0-7923-8496-2.

[12] KELLY,A.: Concise Encyclopedia of Composite materials, Pergamon Press, Oxford, 1989.

[13] http://www.engidesk.com/publishing-area/Mechanically-fastendedjoints.aspx

[14] XIAO,Y., ISHIKAWA,T.: Bearing Strength and Failure Behavior Of Bolted Composite Joints (Part I: Experimental Investigation), Composite Science Technology, 2005, 65, pp.1022-1031.

[15] CAMANHO,P.P., LAMBERT,M.: A Design Methodology for Mechanically Fastened Joints in Laminated Composite Materials, Composites Science and Technology, 2006, 66, pp.3004-3020.

[16] ESENDEMIR,U., ONDURUCU,A.: Comparasion of Bolted Joints with Two Different Clearance Types, Indian Journal of Engineering \& Materials Science, August 2011, Vol.18, pp.283-292.

[17] TOPPUL,S.D., FINNEGAN,J., GIBSON,R.F.: Mechanics of Mechanically Fastened Joints in Polymer-Matrix Composite Structures - A review Composite Science Technology, 2009, 69, pp. $301-329$

\title{
Mehaničke karakteristike spojeva između staklenim vlaknima ojačanih kompozitnih cevi i čeličnog cilindra ostvarenih pomoću različitih spojenih elemenata
}

\begin{abstract}
U ovom radu prikazani su rezultati zateznog ispitivanja specifičnih podsklopova dva elementa, spojenih pomoću mehaničkih sredstava za spajanje. Jedan element je specifična cev malog prečnika. Ovaj element je proizveden tehnologijom mokrog namotavanja koristeći stakleno vlakno impregnisano poliestarskom smolom. Drugi element je cilindrični čelični deo, dobijen standardnom obradom. Navedeni su osnovni podaci o kompozitnim materijalima i mehaničkim sredstvima za spajanje. Pinovi i prstenovi su dva korišćena mehanička sredstva za spajanje. Podaci o izradi uzoraka cevi i spajanju cevi stakleno vlakno/poliestarska smola i cilindra pomoću pinova i prstenova su prikazani. Podsklopovi specifični kompozitni deo/metalni deo, spojeni pomenutim mehaničkim sredstvima za spajanje, bili su izloženi dejstvu aksijalnog zateznog opterećenja. Određena je zatezna prekidna sila sklopova i prikazan je uticaj broja pinova na zateznu prekidnu silu. Opisan je mehanizam oštećenja specifične kompozitne cevi, spojene pomoću pinova i prstenova.
\end{abstract}

Ključne reči: polimerni materijali, kompozitni materijali, stakleno vlakno, mokro namotavanje, cev, čelik, prsten, mehaničko spajanje, mehaničke karakteristike, zatezna čvrstoća.

\section{Механические свойства соединений между армированными стекловолокном композитными трубами и стальными поверхностями цилиндра, реализующимися использованием различных соединяющих элементов}

\begin{abstract}
В данной статье представлены результаты испытаний на растяжение конкретных специфических узлов два элемента, собранных механическими средствами для подключения. Одним из элементов является специфическая композитная труба малого диаметра. Этот элемент изготовлен путём технологии мокрой намотки с использованием стекловолокна, пропитанного полиэфирной смолой. Второй элемент представляет собой цилиндрическую стальную деталь, полученную с помощью стандартной механической обработки. Здесь даны основные данные о композитных материалах и о механических средствах для подключения. В роли штырьков и колец использованы два механических средства для установления соединения. Здесь отображаются данные о подготовке образцов труб, соединяющих трубы из стекловолокна/полиэфирной смолы и цилиндры с помощыю штырьков и колец. Субспецифические композитные части составного / металлической части, соединённые с указанными механическими средствами для подключения, подвергаются воздействию осевых нагрузок на растяжение. Путём растяжения определяется разрушающее усилие упомянутых соединений. Тоже показано влияние количества штырьков на конечную силу натяжения указанного соединения. Описан и механизм повреждения конкретной композитной трубы, соединённой штырьками и кольцами.
\end{abstract} трубы, сталь, кольца, механические застежки, механические свойства, прочность на разрыв. 


\title{
Caractéristiques mécaniques des joints parmi les fibres en verre chez les tubes composites renforcées à petit diamètre et le cylindre métallique en acier obtenus par les différents éléments d'attache
}

\begin{abstract}
Les résultats des recherches sur la tension chez les ensembles de deux éléments spécifiques liés par les moyens mécaniques sont présentés dans ce papier. Un tube spécifique composite à petit diamètre est le premier élément. Cet élément est produit au moyen de la technique de filament enroulé en utilisant le fibre en verre imprégné par la résine polyester. Le second élément est une pièce cylindrique en acier obtenue par le traitement mécanique standard. On a cité les données de base sur les matériaux composites et les moyens mécaniques de jointure. Les chevilles et les anneaux représentent deux moyens mécaniques employés pour la jointure. On a présenté également les données sur la production des échantillons des tubes et sur leur jointure par les fibres en verre / résine polyester et le cylindre joint au moyen des chevilles et des anneaux. Les ensembles spécifiques composites pièce/pièce métallique joints par les moyens mécaniques déjà cités ont été exposés à l'action de la charge axiale de tension.
\end{abstract}

Mots clés: matériaux polymères, matériaux composites, fibre en verre, filament enroulé, tube, acier, anneau, jointure mécanique, caractéristiques mécaniques, résistance à la tension. 